\title{
MALDI spectrometry for salivary samples analysis : a new tool for TTR amyloidosis diagnosis
}

\author{
Julie Seguier ${ }^{1 *}$, Claude Villard ${ }^{2}$, Laurie Anne Maysou ${ }^{3}$, Gilbert Habib ${ }^{3}$, Annie Verschueren ${ }^{4}$, Pauilne Belenotti', \\ Daniel Lafitte ${ }^{2}$, Jacques Serratrice ${ }^{5}$ \\ From First European Congress on Hereditary ATTR amyloidosis \\ Paris, France. 2-3 November 2015
}

\section{Background}

Amyloidosis suffers from a lack of accurate diagnosis tools. It results from a wrong folding of specific proteins and their identification is essential for proper medical care. Today most patients cases are identified thanks to immunohistochemistry analysis after surgery or biopsy on the defective tissues. The aim of our study is to show that diagnosis and typing of TTR amyloidosis can be immediately and rapidly achieved on formaline fixed and paraffin embedded biopsy samples using MALDI spectrometry, and also on salivary samples.

\section{Methods}

Four fresh or formalin fixed and paraffin embedded Myocardial and salivary glands samples were analyzed. A specific de-waxing protocol using trypsic digestion and antigen retrieval was used for paraffin embedded samples. After CHCA matrix deposit, MALDI mass spectromerty acquisition was performed using MALDITOF, MALDI-TOF-TOF et MALDI QIT-TOF. bottom approaches using Electrospray mass spectrometry on high resolution orbitrap instruments was also performed on salivary samples.

\section{Results}

On tissue samples the $\mathrm{m} / \mathrm{z}$ ratio peak was 1366.78 . Its MS/MS analysis allows to obtain $\mathrm{m} / \mathrm{z}$ 1348.70, 1192.59, $1045.54,946.46$ ions, in other words, the following 4 ions coming from the 22-34 TTR-peptide GSPAINVAVHFR. On salivary samples the $\mathrm{m} / \mathrm{z}$ ratio was 15991 matching with transthyretin. After MS/MS fragmentation, $\mathrm{m} / \mathrm{z} 1047.5113$ and 1051.5232 ions were identified

${ }^{1} \mathrm{CHU}$ Timone, Médecine Interne, 1/2, Marseille, France

Full list of author information is available at the end of the article corresponding respectively to Wild Type TTR and mutated THR 49ILE.

\section{Conclusions}

TTR is responsible for amyloid deposits. Formalin fixed and paraffin embedded samples can be ex post analyzed after a specific de-waxing protocol by MALDI mass spectroscopy. Mutated TTR can also be identified on salivary samples. Such an approach has to be evaluated in further studies.

\section{Authors' details}

${ }^{1} \mathrm{CHU}$ Timone, Médecine Interne, 1/2, Marseille, France. ${ }^{2}$ INSERM UMR 911 , Plateforme protéomique PIT2, 2, Marseille, France. ${ }^{3} \mathrm{CHU}$ Timone, Service de Cardiologie, 3, Marseille, France. ${ }^{4} \mathrm{CHU}$ Timone, Service de neurologie, 4, Marseille, France. ${ }^{5}$ Hopitaux Universitaires de Genève, Service de Médecine Interne Génerale, 5, Genève, Suisse.

Published: 2 November 2015

doi:10.1186/1750-1172-10-S1-P46

Cite this article as: Seguier et al:: MALDI spectrometry for salivary samples analysis : a new tool for TTR amyloidosis diagnosis. Orphanet Journal of Rare Diseases 2015 10(Suppl 1):P46.

Submit your next manuscript to BioMed Central and take full advantage of:

- Convenient online submission

- Thorough peer review

- No space constraints or color figure charges

- Immediate publication on acceptance

- Inclusion in PubMed, CAS, Scopus and Google Scholar

- Research which is freely available for redistribution 